\title{
Investigation of the antimicrobial activities of solvent extracts of two endemic species from Turkey: Campanula tomentosa Lam. and Verbascum mykales Bornm.
}

\author{
Esin Poyrazoğlu Çoban ${ }^{10}$, Esra Barıșık (D) \\ ${ }^{1}$ Aydin Adnan Menderes University, Faculty of Arts and Sciences, Department of Biology, Aydin, Turkey
}

ORCID IDs of the authors: E.P.C.. 0000-0002-3921-5362; E.B. 0000-0002-2883-8986

Cite this article as: Poyrazoglu Coban, E., \& Barisik, E. (2021). Investigation of the antimicrobial activities of solvent extracts of two endemic species from Turkey: Campanula tomentosa Lam. and Verbascum mykales Bornm.. Istanbul Journal of Pharmacy, $51(3), 348-356$.

\begin{abstract}
Background and Aims: Campanula tomentosa Lam. and Verbascum mykales Bornm. are endemic species in Turkey. Extracts of these plants contain important natural compounds such as flavonoids, saponins and tannins. This study investigates the antimicrobial effects of leaf extracts of $C$. tomentosa and $V$. mykales against some bacteria and yeasts.

Materials and Methods: Leaves of plant samples were air-dried and ground into powder. Five solvents (ethyl acetate, methanol, acetone, chloroform, boiled water) were used for extraction. Experiments were conducted using these crude extracts on seventeen bacteria, three yeasts and three microfungi. The agar well diffusion method was used for the antimicrobial activities of the extracts. In addition, minimum inhibitory concentrations, minimum bacteriocidal concentration, minimal fungicidal concentrations were carried out.

Results: The ethyl acetate and methanol extracts of $C$. tomentosa and $V$. mykales were found to be highly effective against the tested microorganisms. According to the MIC values, the ethyl acetate extracts of $C$. tomentosa and $V$. mykales had a strong effect $(4-8 \mu \mathrm{g} / \mathrm{mL})$ against Escherichia coli ATCC 35218, Micrococcus luteus ATCC 9341, Streptococcus pneumonia ATCC 27336, Pseudomonas aeruginosa ATCC 35032, Mycobacterium smegmatis ATCC 607, Proteus vulgaris ATCC 33420, Enterococcus faecalis ATCC 29212, Bacillus cereus ATCC 11778, and Bacillus subtilis ATCC 6633. The ethyl acetate extract of $C$. tomentosa had a moderate effect $(64 \mu \mathrm{g} / \mathrm{mL})$ against Candida albicans ATCC 10231 and Saccharomyces cerevisiae ATCC 9763, and the ethyl acetate extract of $V$. mykales had a moderate effect $(64 \mu \mathrm{g} / \mathrm{mL})$ against Aspergillus flavus ATCC 9807 and Aspergillus niger ATCC 16404. However, the boiled water extract of $C$. tomentosa and $V$. mykales had no effect on the tested microorganisms.

Conclusion: $C$. tomentosa and $V$. mykales used in the study are endemic plants and their antimicrobial activities are being investigated for the first time. The ethyl acetate extract of both plants was found to be most effective against the Gram (+) and Gram $(-)$ bacteria. However, all extracts of both plants were found to have fewer antimicrobial effects against used yeasts and microfungi. This study demonstrates that plant extracts are more effective against prokaryotic microorganisms than eukaryotes. Keywords: Campanula tomentosa and Verbascum mykales, antimicrobial activity, agar well diffusion, MIC/MBC/MFC
\end{abstract}

\section{INTRODUCTION}

Humans have used plants as food, spices, textiles, perfumes, and medicines for centuries. The World Health Organization (WHO) has reported that approximately 20000 plants are used as medicine. The number of plants used as medicine is estimated to be 
around 500 in Turkey (Baytop, 1999; Faydaoğlu \& Sürücüoğlu, 2011; Temel, Tınmaz, Öztürk \& Gündüz, 2018; Yaldız \& Çamlıca, 2018). Wild plants have been used for treatment since ancient times by people living in Anatolia as in other societies (Faydaoğlu \& Sürücüoğlu, 2013). The method of treatment with herbs was applied for the first time in the civilizations of Sumer, Akkad and Assyria, which were established in Mesopotamia (Dar, Shahnawaz, \& Qazi, 2016). Wild plants are used as alternative treatments all over the world today. Therefore, as an alternative to synthetic drugs, interest in the use of herbal medicines has increased in the developing world. Herbs are widely used as an alternative treatment in Europe, North America and some developed countries (Keskin, 2018).

The genus Campanula belongs to the Campanulaceae family and involves 300 species (Figure 1). Many Campanula species grow in Asia, the Black Sea and the Mediterranean region. There are many endemic Campanula species in Turkey. (Ozhatay, Kultur, \& Aslan, 2009). Studies on the ethnobotanical use and biological activity of various Campanula species have been conducted by many researchers in Turkey (Buruk, Sokmen, Aydin, \& Erturk, 2006; Benli, Bingöl, Geven, Güney, \& Yiğit; 2008; Tosun, Kahrıman, Çoşkunçelebi, Genç, Alpay Karaoglu, \& Yaylı, 2011; Sinek, Yılmaz İskender, Yaylı, Alpay Karaoglu, \& Yaylı, 2012; Usta, Birinci Yildirim, \& Ucar Turker, 2014). A large number of substances from the root, stem and leaf structures of plants that can inhibit the growth of microorganisms were analyzed. The flavonoids and anthocyanins such as cyanidinand delphinidin were isolated from the Campanula genus. Campanula species have been used in folk medicine for therapy of tonsillitis, laryngitis, and bronchitis. Furthermore, they have antioxidant, antiviral, and antiallergic properties (Alhage, Elbitar, Taha, \& Benvegnu, 2018; Herkul \& Köroğlu, 2019).

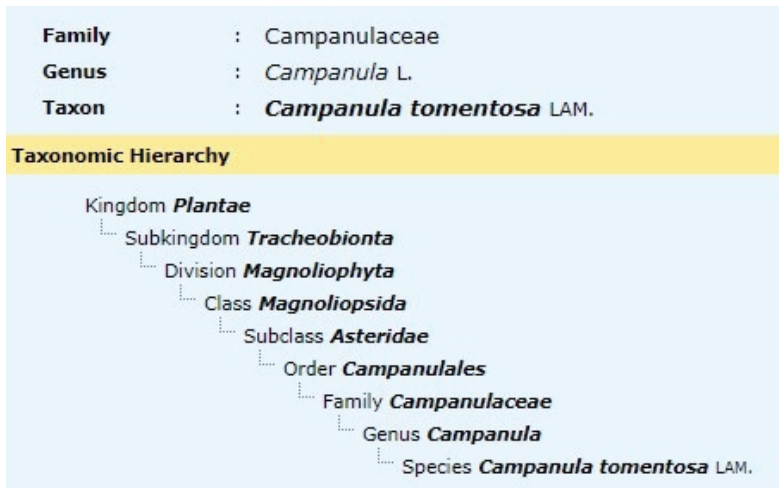

Figure 1. General taxon information of Campanula tomentosa Lam. (Turkish Plants Data Service) (www.tubives.com).

Verbascum belongs tothe Scrophulariaceae family and comprisesof 323 species in the world (Figure 2). The genus includes 245 species in Turkey and the endemism ratio of this genus is very high (79\%) (Dulger \& Dulger, 2018). The Verbascum species has been used as folk medicine since ancient times all over the world. Particularly, flowers and leaves of plants have been used to treat respiration disorders in phytotherapy. Ingredients of the plant, such as flavonoids, glycosides, phenylethanoids, iridoids, saponins, monoterpene and neolignans, have expectorant, diuretic and relaxing properties (Kahraman, Tatlı, Kart,
Ekizoğlu, \& Akdemir, 2018). Flowers containing plant phenyl porpanoids especially have anti-inflammatory effects (Karalija, Parić, Dahija, Bešta-Gajević, \& Zeljković, 2018).

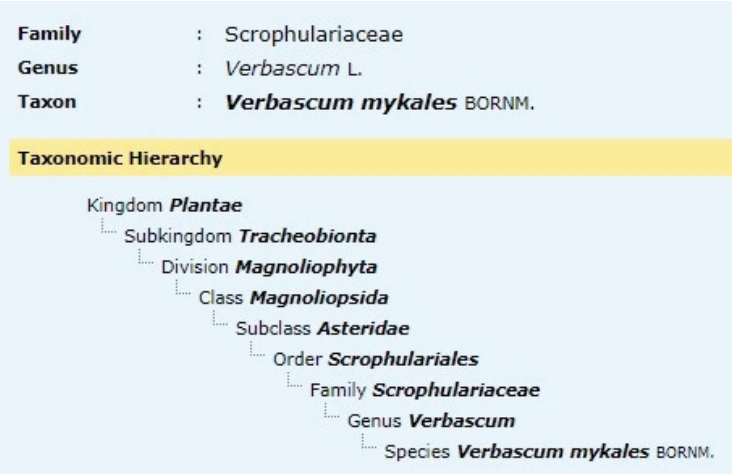

Figure 2. General taxon information of Verbascum mykales Bornm. (Turkish Plants Data Service) (www.tubives.com).

The antimicrobial effect of Campanula lyrata Lam. subsp. lyrata (leaf and flower) methanol extract was analyzed against E. gallinarum CDC-NJ-4, E. faecalis ATCC 29212, B. subtilis RSHI, E. coli RSHI, Shigella sp., E. coli ATCC 25922, S. pyogenes ATCC 19615, S. aureus ATCC 29213, L. monocytogenes ATCC 7644, P. aeruginosa ATCC27853, S. cerevisiae (Pakmaya), C. albicans 845981, C. crusei ATCC 6258 and C. albicans 900628. It was revealed that C. lyrata subsp. lyrata extract was effective against B. subtilis and S. aureus. The minimum inhibitory concentration of C. lyrata subsp. lyrata extract was determinated as $29 \mathrm{mg} / \mathrm{mL}$ for B. subtilis and 14.5 mg/mL for S. aureus (Benli, Bingol, Geven, Guney \& Yigit, 2008). Antimicrobial activities of the dichloromethane, ethanol: water $(70: 30 \mathrm{v} / \mathrm{v})$, water, and methanol extracts of Verbascum macrurum Ten. leaves were examined and it was demonstrated that the ethanol: water extract was the most effective (Guarino, 2002). The ethanolic extract of V. qulebrium Boiss. was tested against S. aureus, S. typhi, S. pastorianus, E. coli, B. subtilis and $P$. aeruginosa and the best inhibition effect was obtained against the Gram (+) bacteria B. subtilis and the yeast S. pastorianus (Khafagi, 2001). Antimicrobial effect of the extracts of V. olympicum Boiss., V. prusianum Boiss. and V. bombyciferum Boiss. were evaluated against Gram (+) and Gram (-) bacteria, and yeasts. It was shown that Verbascum species had antimicrobial activity against the Gram (+) bacteria and the yeast, but no activity was seen against the Gram (-) bacteria (Dulger, Kirmizi, Arslan \& Guleryuz, 2002).

In this study, antimicrobial activities for the solvent extracts of $C$. tomentosa and $V$. mykales, two endemic plant species from Aydın-Turkey, were examined against some Gram (+) and Gram (-) bacteria, yeasts and microfungi.

\section{MATERIALS AND METHODS}

\section{Plant materials}

The sample of leaves of C. tomentosa was collected from Aydın, Doğanbey village (Turkey) in 2018 (Figure 3a, b) and the leaf sample of $V$. mykales was collected from Aydın, Söke/Samsun Mountain (Turkey) in 2017 (Figure 4a, b). The plants were authenticated by Dr. Özkan EREN. Leaf samples from these plants were collected in an amountsuitable to be used in the study 


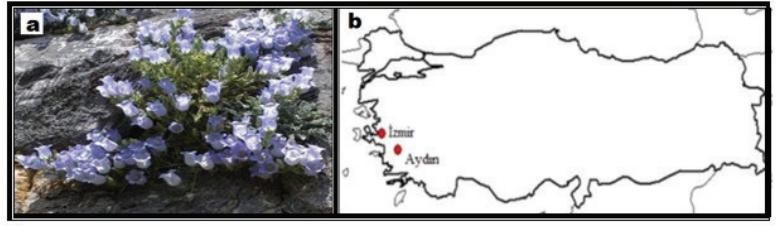

Figure 3. a. Campanula tomentosa Lam. (Eren ve Şentürk, 2018) b.The geographical distribution of Campanula tomentosa Lam. endemic species in Turkey (www.tubives.com).

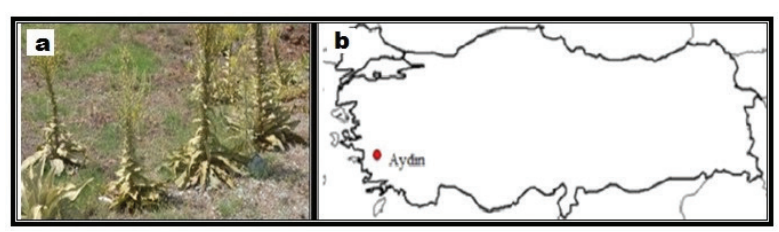

Figure 4. a. Verbascum mykales Bornm.(www.turkiyebitkileri.com) b.The geographical distribution of Verbascum mykales Bornm endemic species in Turkey (www.tubives.com).

without damaging the plant by Dr. Özkan EREN. Both plants are under protection in Turkey. The herbarium numbers of $V$. mykales and C. tomentosa are AYDN 2603 and AYDN 2604, respectively.

\section{Preparation of plant extracts}

Leaf of the plant samples were washed with distilled water and air-dried. Dried leaf was powdered and 15 grams of the materials were extracted separately in $150 \mathrm{~mL}$ of ethyl acetate, methanol, chloroform, acetone and boiled water in a Soxhlet apparatus for 6 h (Göse \& Hacıoğlu Doğru, 2021). Then, the extract was filtered and concentrated by rotary evaporator. The dry powder extracts $(0.5-1.0 \mathrm{~g})$ were kept at $+4^{\circ} \mathrm{C}$ and the extracts were dissolved in $5 \%$ DMSO just before the activity studies were started (Törün, Çoban, Bıyık, \& Barışık, 2017; Çoban, Bıyık, Törün, \&Yaman, 2017).

\section{Microorganisms and condition for cultivation}

Seventeen bacteria, three yeasts and three microfungi were used to test the antimicrobial effect. The Gram (-) strains were Escherichia coli ATCC 35218, Enterobacter aerogenes ATCC 13048, Salmonella typhimurium ATCC 14028, Klebsiella pneumoniae ATCC 13882, Pseudomonas aeruginosa ATCC 35032, Serratia marcescens ATCC 13880, and Proteus vulgaris ATCC 33420. The Gram (+) strains were Micrococcus luteus ATCC 9341, Staphylococcus aureus ATCC 25923, Staphylococcus epidermidis ATCC 12228, Streptococcus pneumoniae ATCC 27336, Corynebacterium xerosis ATCC 373, Mycobacterium smegmatis ATCC 607, Enterococcus faecalis ATCC 29212, Listeria monocytogenes ATCC 19112, Bacillus cereus ATCC 11778, and Bacillus subtilis ATCC 6633. The yeast strains were Candida albicans ATCC 10231, Candida utilis ATCC 9950, Saccharomyces cerevisiae ATCC 9763, Aspergillus flavus ATCC 9807, Aspergillus niger ATCC 16404 and Aspergillus oryzae ATCC 10124. The strains were obtained from the American Type Culture Collection (ATCC, Rockville, MD, USA). The bacterial strains were cultered in Tryptic Soy Agar (TSA) and Brain Heart Infusion Agar (BHIA) at $30-37^{\circ} \mathrm{C}$ for $24 \mathrm{~h}$. The yeast strains were cultured in Malt Extract Agar (MEA) at $30^{\circ} \mathrm{C}$ for $24 \mathrm{~h}$ (Çoban, Erçin, Törün, \& Bıyık, 2018; Bıyık, Onur, Törün, \& Çoban, 2018). The microfungi strains were cultured in Potato Dextrose Agar (PDA) at $25-27^{\circ} \mathrm{C}$ for 5-7 days (Okoye, Uba, Dike, \& Eziefule, 2020).

\section{Antimicrobial assays}

The antimicrobial activities of the two plants were determined by the agar well diffusion method (Collins, Lyne, Grange, \& Falkinham, 2004; CLSI, 2004; CLSI, 2015; Balouiri, Sadiki, \& Ibnsouda, 2016; EUCAST, 2019). The minimum inhibitory concentrations (MIC) were obtained by the broth dilution method (Jorgensen \& Ferraro, 2009; CLSI, 2009; CLSI, 2013). The minimum bacteriocidal concentrations (MBC) and the minimum fungicidal concentrations (MFC) were tested (Zamri, Bakar, Noor, \& Fuad, 2020; Stojkovi'c, Dias, Drakuli'c, Barros, Stevanovi'c, Ferreira, \& Sokovi'c, 2020).

\section{Disc diffusion method}

Screening for antimicrobial activities were carried out by the agar well diffusion method against test microorganisms (Collins, Lyne, Grange, \& Falkinham, 2004; CLSI, 2004; CLSI, 2015; EUCAST, 2019). The inoculum suspensions of the tested bacteria and yeasts were prepared from the broth cultures (18-24 h) and the turbidity adjusted using a $0.5 \mathrm{McF}$ arland standard tube to give an equivalent concentration of $1 \times 10^{8}$ bacterial cells/ $\mathrm{mL}$, and $1 \times 10^{6}$ yeast cells/mL (Çoban, Erçin, Törün, \& Bıyık, 2018; Oyeka, Asegbeloyin, Babahan, Eboma, Okpareke, Lane, Ibezim, Bıyık, Törün, \& Izuogu, 2018). The microfungi suspensions were adjusted to $1 \times 10^{4}$ conidia cells $/ \mathrm{mL}$ (Ismaiel \& Tharwat, 2014). In order to test the antimicrobial activity of the plants, $20 \mathrm{~mL}$ of Mueller Hinton Agar (MHA) were poured in petri dishes and kept at room temperature to solidify. Then, they were inoculated with strains of bacteria, yeasts and fungi by taking $0.1 \mathrm{~mL}$ from the cell culture media. Then, a hole of $6 \mathrm{~mm}$ in diameter and depth was made on the top of the agar plates with a sterile stick and was filled with $50 \mu \mathrm{L}$ of plant extract $(1000 \mu \mathrm{g} / \mathrm{mL})$. Then, bacterial cultures were incubated at $30-37^{\circ} \mathrm{C}$ for $18-24$ $\mathrm{h}$, and yeast cultures were incubated at $27-30^{\circ} \mathrm{C}$ for $18-24 \mathrm{~h}$. The fungi cultures were incubated at $25-27^{\circ} \mathrm{C}$ for $5-7$ days. At the end ofthe incubation time, the diameters of the inhibition zones formed on the MHA were evaluated in $\mathrm{mm}$. Discs containing Chloramphenicol (30 mg Oxoid), Gentamycin (10 mg Oxoid), Tetracycline (30 mg Oxoid), Erythromycin (15mg Oxoid), Penicillin (10 mg Oxoid), Ampicillin (10 mg Oxoid), Vancomycin (30 mg Oxoid), and Ofloxacin (5 mg Oxoid) for bacteria, Nystatin (100 mg Oxoid) for yeasts, and Clotrimazole (10mg Oxoid) for microfungi were used as positive controls. The measured inhibition zones of the extracts were compared with those of the reference discs (Çoban, Bıyık, Törün, \&Yaman, 2017).

\section{Dilution method}

The antibacterial and antifungal activities of solvent extracts synthesized compounds were examined by preparing a microdilution broth (Jorgensen \& Ferraro, 2009; CLSI, 2009; CLSI, 2013). The analysis was carried out in a sterile 96-well microtitre plate. The suspensions, adjusted as $1 \times 10^{8}$ bacterial cell $/ \mathrm{mL}$, $1 \times 10^{6}$ yeast cells $/ \mathrm{mL}$ and $1 \times 10^{4}$ conidia cells $/ \mathrm{mL}$ for the analysis, were used. Initially, $100 \mu \mathrm{L}$ of Mueller Hinton Broth (MHB) was placed in each well. After, the extracts were added into the first well. Two-fold serial dilutions of the extracts were carried out to determine the MIC, within the concentration range 256 to $0.25 \mu \mathrm{g} / \mathrm{mL}$. Next, $100 \mu \mathrm{L}$ of microorganism suspension was added into each well. The bacterial cultures were incubated at 
Poyrazoğlu Çoban and Barışık. Investigation of the antimicrobial activities of solvent extracts of two endemic species from Turkey: Campanula tomentosa Lam. and Verbascum mykales Bornm.

$30-37^{\circ} \mathrm{C}$, and yeast cultures were incubated at $27-30^{\circ} \mathrm{C}$ for $18-$ $24 \mathrm{~h}$. The fungi cultures were incubated at $25-27^{\circ} \mathrm{C}$ for $5-7$ days. The lowest concentration of antimicrobial agent that resulted in complete inhibition of the microorganisms was represented as MIC ( $\mu \mathrm{g} / \mathrm{mL})$. Streptomycin for bacteria, and fluconazole for yeasts and microfungi were used as positive controls in the dilution method. In each case, the test was performed in triplicate and the results were expressed as means.

\section{Minimum Bacteriocidal Concentration (MBC) / Minimum Fungicidal Concentration (MFC)}

As a result of MIC test was carried out MBC and MFC tests. From each clear well in the MIC assay, $10 \mu \mathrm{L}$ was inoculated and spread onto MHA plates. Then the plates were incubated at $30-37{ }^{\circ} \mathrm{C}$ for $18-24$ hours for the bacteria, and at $25-27^{\circ} \mathrm{C}$ for 5-7 days for the fungi. The MBC and MFC were identified as the lowest concentration of extract that did not grow any bacteria and fungi on the MHA plates (Zamri, Bakar, Noor, \& Fuad,
2020; Stojkovi'c, Dias, Drakuli'c, Barros, Stevanovi'c, Ferreira, \& Sokovi'c, 2020).

\section{Statistical analysis}

Mean values and standard deviation calculations were made using SPSSv22 (Statistical Package for Social Sciences).

\section{RESULTS AND DISCUSSION}

\section{Antimicrobial analysis}

The antimicrobial activity of the ethyl acetate, methanol, chloroform, acetone and boiled water extracts of C. tomentosa and $V$. mykales were researched and the results are given Table 1 and 3 . Also, the results of the reference antibiotics used are showed in Table 2.

Among the plant extracts tested, the ethyl acetate extracts of $C$. tomentosa and $V$. mykales indicated a high effect against

Table 1. Antimicrobial activities of the extracts of $C$. tomentosa and $V$. mykales against some microorganisms (Inhibition zone $\mathrm{mm}$ ).

\begin{tabular}{|c|c|c|c|c|c|c|c|c|c|c|}
\hline \multirow{4}{*}{ Test Microorganisms } & \multicolumn{10}{|c|}{ Inhibition zones (mm) } \\
\hline & \multicolumn{10}{|c|}{ Plant Extracts } \\
\hline & \multicolumn{5}{|c|}{ Campanula tomentosa Lam. } & \multicolumn{5}{|c|}{ Verbascum mykales Bornm. } \\
\hline & EA & C & M & Ac & BW & EA & C & M & Ac & BW \\
\hline Escherichia coli & $17.33 \pm 2.51$ & - & _ & _ & _ & $25.33 \pm 2.51$ & _ & _ & _- & - \\
\hline Enterobacter aerogenes & $17.66 \pm 2.51$ & - & _ & _- & _ & $19.33 \pm 2.08$ & _ & - & - & - \\
\hline Salmonella typhimurium & $15.33 \pm 2.51$ & - & $9.66 \pm 0.57$ & _ & _ & $19.66 \pm 0.57$ & - & _ & _ & - \\
\hline Micrococcus luteus & $21.33 \pm 1.52$ & - & $8.66 \pm 0.57$ & - & - & $27.33 \pm 2.51$ & - & $11.00 \pm 1.00$ & $10.66 \pm 1.15$ & \\
\hline Staphylococcus aureus & $13.33 \pm 0.57$ & - & $14.33 \pm 0.57$ & - & - & $16.00 \pm 2.64$ & - & $12.33 \pm 2.51$ & $11.66 \pm 2.08$ & - \\
\hline Staphylococcus epidermidis & $17.00 \pm 2.64$ & - & $9.33 \pm 0.57$ & - & - & $19.33 \pm 1.15$ & - & $10.00 \pm 0.00$ & $11.66 \pm 2.08$ & - \\
\hline Klebsiella pneumoniae & $19.33 \pm 0.57$ & - & $12.66 \pm 0.57$ & - & - & $18.00 \pm 3.00$ & - & - & - & - \\
\hline Streptococcus pneumoniae & $15.66 \pm 0.57$ & - & $9.33 \pm 0.00$ & - & - & $25.00 \pm 2.00$ & - & $11.66 \pm 2.88$ & & - \\
\hline Pseudomonas aeruginosa & $12.00 \pm 1.00$ & - & & - & - & $23.00 \pm 2.64$ & $9.66 \pm 0.57$ & $23.33 \pm 2.88$ & $18.66 \pm 2.08$ & - \\
\hline Corynebacterium xerosis & $19.00 \pm 2.64$ & - & $12.33 \pm 0.57$ & - & - & $19.66 \pm 0.57$ & - & - & - & - \\
\hline Mycobacterium smegmatis & $22.33 \pm 1.52$ & - & $10.33 \pm 0.57$ & - & - & $19.33 \pm 1.15$ & - & - & - & - \\
\hline Listeria monocytogenes & $19.33 \pm 0.57$ & - & $11.00 \pm 0.00$ & $10.33 \pm 0.57$ & - & $19.00 \pm 1.73$ & - & - & - & - \\
\hline Serratia marcescens & $21.66 \pm 2.08$ & - & $8.66 \pm 0.57$ & - & - & $21.66 \pm 2.88$ & - & - & - & - \\
\hline Proteus vulgaris & $24.33 \pm 1.15$ & - & $11.66 \pm 1.15$ & - & - & $20.33 \pm 0.57$ & - & - & - & - \\
\hline Enterococcus faecalis & $23.00 \pm 1.00$ & - & $10.66 \pm 1.15$ & - & - & $15.00 \pm 1.73$ & - & - & - & - \\
\hline Bacillus cereus & $24.00 \pm 1.00$ & - & $14.33 \pm 1.15$ & $10.33 \pm 0.57$ & - & $19.33 \pm 3.21$ & - & $12.00 \pm 2.00$ & $12.00 \pm 1.73$ & - \\
\hline Bacillus subtilis & $23.33 \pm 1.52$ & - & $11.33 \pm 0.57$ & $9.66 \pm 0.57$ & - & $23.00 \pm 1.73$ & - & $11.33 \pm 1.52$ & $11.66 \pm 1.52$ & - \\
\hline Candida albicans & $13.66 \pm 1.15$ & & $9.66 \pm 1.15$ & $10.33 \pm 0.57$ & - & - & - & - & - & - \\
\hline Candida utilis & - & - & - & - & - & $11.00 \pm 1.00$ & - & - & $11.33 \pm 2.30$ & - \\
\hline Saccharomyces cerevisiae & $12.33 \pm 1.15$ & & $10.00 \pm 0.00$ & - & - & - & & & - & - \\
\hline Aspergillus flavus & - & - & - & - & - & $12.33 \pm 2.51$ & - & - & - & - \\
\hline Aspergillus niger & - & - & - & - & - & $12.66 \pm 0.57$ & - & - & - & - \\
\hline Aspergillus oryzae & - & - & - & - & - & - & - & - & - & - \\
\hline
\end{tabular}


Table 2. Inhibition zone diameter of the reference antibiotics to test microorganisms ( $\mathrm{mm}$ ).

\begin{tabular}{|c|c|c|c|c|c|c|c|c|c|c|}
\hline \multirow{3}{*}{ Test Microorganisms } & \multicolumn{10}{|c|}{ Inhibition zones (mm) } \\
\hline & \multicolumn{10}{|c|}{ Reference antibiotics } \\
\hline & $\mathrm{c} 30$ & CN10 & TE30 & E15 & P10 & AMP10 & VA30 & 0FX5 & NS100 & CTL10 \\
\hline Escherichia coli & 24 & 21 & 15 & 11 & 16 & - & 23 & 28 & NT & NT \\
\hline Enterobacter aerogenes & 19 & 20 & 14 & - & - & - & - & 19 & NT & NT \\
\hline Salmonella typhimurium & 17 & 16 & 15 & 8 & 15 & 8 & 21 & 25 & NT & NT \\
\hline Micrococcus luteus & 25 & 15 & 26 & 30 & 13 & 28 & 14 & 24 & NT & NT \\
\hline Staphylococcus aureus & 23 & 20 & 22 & 23 & 12 & 20 & 13 & 23 & NT & NT \\
\hline Staphylococcus epidermidis & 22 & 17 & 19 & 11 & 11 & 17 & 12 & 22 & NT & NT \\
\hline Klebsiella pneumoniae & 21 & 19 & 20 & 14 & 18 & - & 23 & 27 & NT & NT \\
\hline Pseudomonas aeruginosa & 22 & 20 & 20 & 21 & 14 & - & 18 & 29 & NT & NT \\
\hline Corynebacterium xerosis & 20 & 17 & 25 & 26 & 14 & 27 & 21 & 22 & NT & NT \\
\hline Mycobacterium smegmatis & 23 & 18 & 26 & 25 & 16 & 19 & 20 & 30 & NT & NT \\
\hline Listeria monocytogenes & 19 & 14 & 12 & - & 10 & 12 & 25 & 29 & NT & NT \\
\hline Serratia marcescens & 23 & 19 & 13 & - & 18 & 19 & 27 & 27 & NT & NT \\
\hline Proteus vulgaris & 17 & 24 & 16 & 20 & 15 & - & 24 & 26 & NT & NT \\
\hline Enterococcusfaecalis & 16 & 11 & 19 & - & 12 & 14 & 20 & 28 & NT & NT \\
\hline Streptococcus pneumoniae & 24 & 20 & 25 & 15 & 19 & 14 & 29 & 28 & NT & NT \\
\hline Bacillus cereus & 23 & 24 & 25 & 26 & 10 & - & 21 & 28 & NT & NT \\
\hline Bacillus subtilis & 22 & 20 & 12 & 25 & 11 & - & 20 & 27 & NT & NT \\
\hline Candida albicans & NT & NT & NT & NT & NT & NT & NT & NT & 22 & NT \\
\hline Candida utilis & NT & NT & NT & NT & NT & NT & NT & NT & 21 & NT \\
\hline Saccharomyces cerevisiae & NT & NT & NT & NT & NT & NT & NT & NT & 15 & NT \\
\hline Aspergillus flavus & NT & NT & NT & NT & NT & NT & NT & NT & NT & 23 \\
\hline Aspergillus niger & NT & NT & NT & NT & NT & NT & NT & NT & NT & 24 \\
\hline Aspergillus oryzae & NT & NT & NT & NT & NT & NT & NT & NT & NT & 24 \\
\hline $\begin{array}{l}\text { (-): Zone did not occur. NT: Not te } \\
\text { C30: Chloramphenicol ( } 30 \mathrm{mg} 0 x \\
\text { AMP10: Ampicillin (10 mg 0xoid), } \\
\text { (100 mg 0xoid), CTL10: Clotrimaz }\end{array}$ & $\begin{array}{l}\text { 10: } \\
\text { enic }\end{array}$ & $\begin{array}{l}\text { tamyci } \\
(10 \mathrm{mg}\end{array}$ & $\begin{array}{l}0 \mathrm{mg} \\
\text { id), }\end{array}$ & 1,1 & $(30$ & $\begin{array}{l}\text { (30 m } \\
\text { id), } 0\end{array}$ & $\begin{array}{l}\text { id), } \\
\text { flox }\end{array}$ & $\begin{array}{l}\text { ythr } \\
\text { mg }\end{array}$ & $\begin{array}{l}\text { (15m } \\
\text { NS10 }\end{array}$ & $\begin{array}{l}\text { id), } \\
\text { statin }\end{array}$ \\
\hline
\end{tabular}

some Gram (-) and Gram (+) bacteria (Table 1). The ethyl acetate extract of C. tomentosa showed strong activity (19-24 $\mathrm{mm}$ ) against M. luteus, K. pneumoniae, C. xerosis, M. smegmatis, L. monocytogenes, S. marcescens, P. vulgaris, E. faecalis, B. cereus, and B. subtilis. On the other hand, the ethyl acetate extract of V. mykales Bornm. demostrated more powerful effects (18-27 $\mathrm{mm}$ ) against E. coli, E. aerogenes, S. typhimirium, M. luteus, S. epidermidis, K. pneumoniae, S. pneumonia, P. aeruginosa, C. xerosis, M. smegmatis, L. monocytogenes, S. marcescens, P. vulgaris, B. Cereus, and B. subtilis (Figure $5 \mathrm{a}, \mathrm{b}$ ). The ethyl acetate extract of C. tomentosa showed significant activity (12-17 mm) against $E$. coli, E. aerogenes, S. typhimirium, S. aureus, S. epidermidis, S. pneumonia, P. aeruginosa, C. albicans, and S. cerevisiae. The methanole extract of $C$. tomentosa showed a remarkable effect (12-14 $\mathrm{mm}$ ) against S. aureus, K. pneumoniae, C. xerosis, and B. cereus. The same extract and the acetone extract of the plant indicated a slight effect (8-11 mm) against S. typhimirium, M. luteus, S. epidermidis, S. pneumonia, M. smegmatis, L. monocytogenes, S.

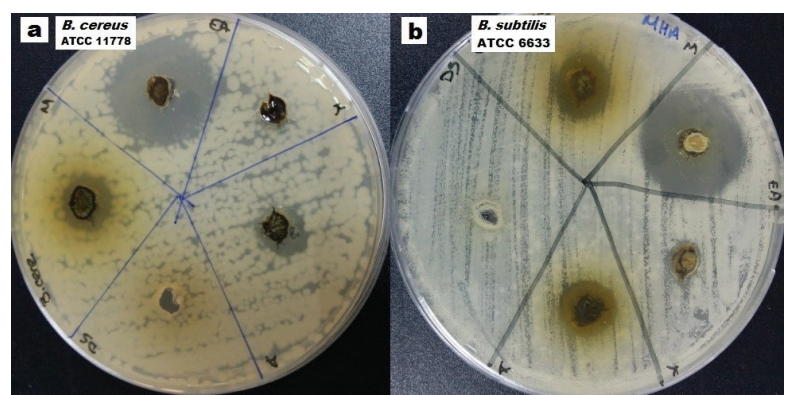

Figure 5. a. Effect of ethyl acetate, methanol, chloroform, acetone, boiled water extracts of Campanula tomentosa Lam. against Bacillus cereus ATCC 11778 b. Effect of ethyl acetate, methanol, chloroform, acetone, boiled water extracts of Verbascum mykales Bornm. against $B a-$ cillus subtilis ATCC 6633. EA: Ethyl Acetate, M:Methanol, K:Chloroform, A:Acetone, DS: Boiled Water.

marcescens, P. vulgaris, E. faecalis, B. cereus, B. subtilis, C. albicans, and S. cerevisiae. However, the chloroform and boiled water ex- 
Poyrazoğlu Çoban and Barışık. Investigation of the antimicrobial activities of solvent extracts of two endemic species from Turkey: Campanula tomentosa Lam. and Verbascum mykales Bornm.

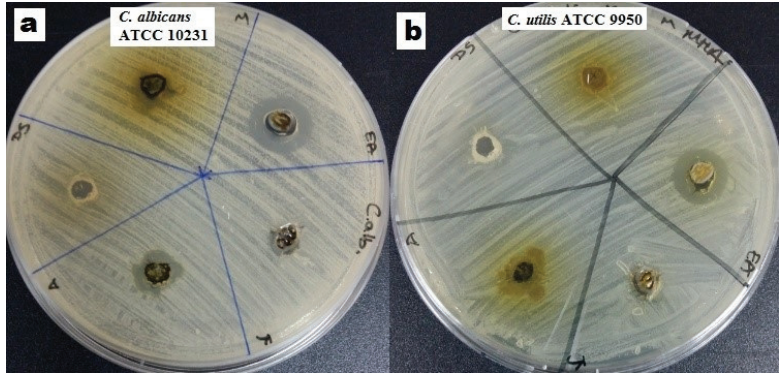

Figure 6. a. Effect of ethyl acetate, methanol, chloroform, acetone, boiled water extracts of Campanula tomentosa Lam. against Candida albicans ATCC 10231 b. Effect of ethyl acetate, methanol, chloroform, acetone, boiled water extracts of Verbascum mykales Bornm. against Candida utilis ATCC 9950. EA: Ethyl Acetate, M:Methanol, K:Chloroform, A:Acetone, DS: Boiled Water.

tracts of C. tomentosa had no effect against C. albicans (Figure 6a). The ethyl acetate extract of $V$. mykales Bornm. displayed a noteworthy effect (12-16 mm) against S. aureus, E. faecalis, A. flavus, and A. niger. The methanole and acetone extracts of the plant demostrated a high effect $(18-23 \mathrm{~mm})$ against $P$. aerugi- nosa while the same extracts had a moderate effect $(12 \mathrm{~mm})$ against $B$. cereus. However, the ethyl acetate and acetone extracts of $V$. mykales Bornm. had a low effect $(9-11 \mathrm{~mm})$ against C. utilis (Figure 6b). Otherwise, The boiling water extract of the plant has no effect against tested microorganisms.

According to the MIC/MBC/MFC values in Table 3, the ethyl acetate extract of $C$. tomentosa had a strong effect $(8 \mu \mathrm{g} / \mathrm{mL})$ against $M$. smegmatis, P. vulgaris, E. faecalis, B. cereus, and B. subtilis. On the other hand, the ethyl acetate extract of the plant showed a significant effect (16-64 $\mathrm{\mu g} / \mathrm{mL}$ ) against other bacteria and yeasts. Also, the methanol and acetone extracts of the plant had a very low effect (128-256 $\mathrm{\mu g} / \mathrm{mL})$ against many bacteria and two yeasts. The ethyl acetate extract of $V$. mykales indicated a very strong effect $(4-8 \mu \mathrm{g} / \mathrm{mL})$ against $E$. coli, $M$. luteus, S. pneumonia, P. aeruginosa, and B. subtilis. Besides, the same extract of plant demostrated an appreciable effect (16$64 \mu \mathrm{g} / \mathrm{mL}$ ) against other bacteria, one yeast and two microfungi. However, the methanole and acetone extracts of the plant showed a remarkable effect $\left(8-16 \mu \mathrm{g} \mathrm{mL} \mathrm{L}^{-1}\right)$ against $P$. aeruginosa. Otherwise, the chloroform, methanole and acetone

\section{Table 3. Antimicrobial activities of the extracts of $C$. tomentosa and $V$. mykales against some microorganisms} (MIC/MBC/MFC), $(\mu \mathrm{g} / \mathrm{mL})$.

\begin{tabular}{|c|c|c|c|c|c|c|c|c|c|c|}
\hline \multirow{3}{*}{ Test Microorganisms } & \multicolumn{10}{|c|}{ MIC/MBC/MFC $(\mu \mathrm{g} / \mathrm{mL})$} \\
\hline & \multicolumn{4}{|c|}{ Campanula tomentosa Lam. } & \multicolumn{4}{|c|}{ Verbascum mykales Bornm. } & \multicolumn{2}{|c|}{$\begin{array}{l}\text { Reference antibi- } \\
\text { otics }\end{array}$} \\
\hline & EA & C & M & A & EA & C & M & A & STR & FLK \\
\hline Escherichia coli & $32 / 64$ & - & - & - & $4 / 8$ & - & - & - & 64 & NT \\
\hline Enterobacter aerogenes & $32 / 64$ & - & - & - & $16 / 32$ & - & - & - & 64 & NT \\
\hline Salmonella typhimurium & $32 / 64$ & - & $256 />256$ & _ & $16 / 32$ & _- & _- & _- & 64 & NT \\
\hline Micrococcus luteus, & $16 / 32$ & - & $256 />256$ & - & $4 / 8$ & - & - & - & 32 & NT \\
\hline Staphylococcus aureus & $32 / 64$ & - & $64 / 128$ & - & $32 / 64$ & - & $>256 />256$ & $128 / 256$ & 32 & NT \\
\hline Staphylococcus epidermidis & $32 / 64$ & - & $256 />256$ & - & $16 / 32$ & - & $>256 />256$ & $128 / 256$ & 32 & NT \\
\hline Klebsiella pneumoniae & $16 / 32$ & - & $64 / 128$ & - & $16 / 32$ & - & - & - & 64 & NT \\
\hline Streptococcus pneumoniae & $32 / 64$ & - & $256 />256$ & - & $4 / 8$ & - & $>256 />256$ & - & 128 & NT \\
\hline Pseudomonas aeruginosa & $64 / 128$ & - & - & - & $8 / 16$ & $256 />256$ & $8 / 16$ & $16 / 32$ & 64 & NT \\
\hline Corynebacterium xerosis & $16 / 32$ & - & $64 / 128$ & - & $16 / 32$ & - & - & - & 64 & NT \\
\hline Mycobacterium smegmatis & $8 / 16$ & - & $128 / 256$ & - & $16 / 32$ & - & - & - & 128 & NT \\
\hline Listeria monocytogenes & $16 / 32$ & - & $128 / 256$ & $256 />256$ & $16 / 32$ & - & - & - & 64 & NT \\
\hline Serratia marcescens & $16 / 32$ & - & $256 />256$ & - & $16 / 32$ & - & - & - & 64 & NT \\
\hline Proteus vulgaris & $8 / 16$ & - & $128 / 256$ & - & $16 / 32$ & - & - & - & 64 & NT \\
\hline Enterococcus faecalis & $8 / 16$ & - & $128 / 256$ & - & $32 / 64$ & - & - & - & 64 & NT \\
\hline Bacillus cereus & $8 / 16$ & - & $64 / 128$ & $128 / 256$ & $16 / 32$ & - & $64 / 128$ & $64 / 128$ & 64 & NT \\
\hline Bacillus subtilis & $8 / 16$ & - & $128 / 256$ & $256 />256$ & $8 / 16$ & - & $128 / 256$ & $128 / 256$ & 64 & NT \\
\hline Candida albicans & $64 / 128$ & - & $256 />256$ & $128 / 256$ & - & - & - & - & NT & 64 \\
\hline Candida utilis & - & - & - & - & $128 / 256$ & - & - & $128 / 256$ & NT & 64 \\
\hline Saccharomyces cerevisiae & $64 / 128$ & - & $128 / 256$ & - & - & - & - & - & NT & 64 \\
\hline Aspergillus flavus & - & - & - & - & $64 / 128$ & - & - & - & NT & 64 \\
\hline Aspergillus niger & - & - & - & - & $64 / 128$ & - & - & - & NT & 64 \\
\hline
\end{tabular}


extracts had a slight activity $(128-256 \mu \mathrm{g} / \mathrm{mL})$ against some bacteria and one yeast (Table 3).

The antimicrobial effect of methanol, acetone and ethyl acetate extracts obtained from V. pinnatifidum Vahl. and V. antinori Boiss. et Heldr were researched against Gram (+) and Gram (-) bacteria, and C. albicans ATCC 10231. It was found that the $V$. antinori extracts have a greater antimicrobial effect than $V$. pinnatifidum extracts against the test microorganisms (Göse \& Hacıoğlu Doğru, 2021). The methanol, dichloromethane, and aqueous crude extracts of $C$. retrorsa flower, leaf and stem were tested against the microorganisms. It was found that the activities of the dichloromethane extracts of leaves and flowers of C. retrorsa have a moderate effect against $A$. baumanii and $C$. albicans and the methanol and aqueous crude extracts of $C$. retrorsa have no activity against the other bacteria tested and C. albicans (Alhage, Elbitar, Taha, \& Benvegnu, 2020). Himalayan medicinal plants were used traditionally to treat pneumonia and tuberculosis. It has been revealed that the methanol extract of $V$. thapsus leaves has antibacterial activity against S. aureus, S. pneumonia and M. tuberculosis (Muhammad, Shandana, Khushboo, \& Rahila, 2019). Abdallah \& Omar (2019) remarked on the antimicrobial activity of water, ethanol and methanol extracts of the aerial parts of $V$. fruticulosum against an E. coli clinical isolate. The results showed that water and methanol extracts did not inhibit E. coli; however, the ethanol extract repressed growth of $E$. coli. In another study by Dülger \& Dülger (2018), it was reported that the methanol extract obtained from $V$. antinori Boiss. et Heldr. has an antibacterial effect against Gram (+) and Gram (-) bacteria. In asimilar study by Fares (2018), the antimicrobial activity of the methanol, acetone, n-hexane and aqueous extracts of the aerial parts of $V$. fruticulosum were examined against microorganisms. Methanol, acetone and n-hexane extracts of plant has higher activity than the water extract against $S$. aureus, E. coli, P. aeruginosa, E. faecium, S. sonnei, and methicillin-resistant S. aureus (MRSA).The methanol and acetone extracts of plant indicated the strongest inhibition against $P$. aeruginosa $(1.56 \mathrm{mg} / \mathrm{mL})$, E. coli and S. aureus $(6.25 \mathrm{mg} / \mathrm{mL})$. The aqueous extract of plant has effect against S. aureus (MRSA) $3.125 \mathrm{mg} /$ $\mathrm{mL}$ ) while the methanol and $\mathrm{n}$-hexane extracts of plant have effect against E. faecium and S. sonnei $(3.125 \mathrm{mg} / \mathrm{mL})$. The methanol, acetone and $n$-hexane extracts had activity against $C$. albicans and E. floccosum. The highest effect $(1.56 \mathrm{mg} / \mathrm{mL})$ was obtained with the $\mathrm{n}$-hexane extract against E. floccosum. However, the aqueous extract did not have any activity. An antibacterial effect was seen on S. aureus ATCC 6538P (22 mm), B. cereus ATCC 7064 (20 mm), L. monocytogenes ATCC 15313 (14 mm), and M. luteus CCM 169 (17mm). The methanol extract of $V$. mucronatum flowers was tested against E.coli ATCC 25922, E. faecalis ATCC 29212, P. aeruginosa ATCC 27853, S. aureus ATCC 29213, C. albicans ATCC 90028, C. krusei ATCC 6258, and C. parapsilosis ATCC 90018. It was found that V. glabratum subsp. bosnense (K. Maly) Murb. includes quercetin and rosmarinic acid, 4-hydroxybenzoic acid, salicylic acid, morin, and apigenin as bioactive compounds. In addition, the ethanol extracts of $V$. glabratum subsp. bosnense (K. Maly) Murb. had a moderate effect with MIC values of $600 \mu \mathrm{g} / \mathrm{mL}-1200 \mu \mathrm{g} / \mathrm{mL}$ against E. coli, S. aureus, and C. albicans (Karalija, Parić, Dahija, Bešta-Gajević, \& Zeljković, 2018). The phenolic profiles and endogenous hormone levels in embryogenic and nonembryogenic calli of C. tomentosa were analyzed, but an antimicrobial activity study of this en- demic plant species has not been presented in the records (Coşkun, Gemici, \&Yildirim, 2017). In another study, the methanolic extracts of Verbascum cheiranthifolium Boiss. var. asperulum (Boiss.) Murb. Monorg., V. pynostachyum Boiss. \& Heldr and V. orgyale Boiss. \& Heldr.were tested against C. albicans, C. tropicalis, C. parapsilosis, C. utilis, C. glabrata, and C. krusei. It was remarked that $V$. pynostactum and $V$. orygale extracts indicated a higher effect than $V$. cheriantifolium var. asperulum. Particulary, $V$. pycnostachyum extract inhibited C. krusei at the concentration of $62.5 \mu \mathrm{g} / \mathrm{mL}$ (Küçük, Özdemir, İşcan, \& Incesu, 2016). In a similar study, the antibacterial activity of the methanol and acetone leaf extracts of $V$. thapsus were examined against $E$. coli, Y. pestis, B. cereus, P. aeruginosa, L. monocytogenes and S. aureus. It was reported that the methanol extract of this plant has stronger activity than an acetone extract against the tested pathogenic bacteria (Prakash, Rana, \& Sagar, 2016). The antimicrobial effect of the methanol extract of $V$. speciosum leaves was investigated against S. aureus, L. monocytogenes, B. anthracis, B. cereus, S. typhimurium and E. coli. It was found that the extract has remakable activity against L. monocytogenes, B. cereus, S. aureus and S. thyphimurium; even more than penicillin (Nofouzi, Mahmudi, Tahapour, Amini, \&Yousefi, 2016). The antifungal activity of a methanol extract of the aerial part of $V$. speciosum was tested against C. albicans, C. tropicalis, C. parapsilosis, C. krusei, C. dubliniensis, A. flavus, A. niger, Penicillium sp. and Alternaria sp. The highest activity was seen against C. parapsilosis and Alternaria sp. (Nofouzi, 2015). In another study, the antibacterial activity of some Turkish plants was screened against fish pathogens by Türker \& Yıldırım (2015). The ethanol and aqueous crude extracts of C. glomerata L. subsp. hispida (Witasek) Hayek and C. olympica Boiss. were used for the antibacterial activity. It was reported that the ethanol extracts of C. glomerata subsp. hispida and C. olympica have a slight effect (11 mm and $8 \mathrm{~mm}$ ). However, aqueous crude extracts of the plants did not inhibit fish pathogens. In a similar study, the antibacterial effects of ethanol, methanol and water extracts of C. glomerata and C. olympica flowers, leaves and stems were researched against S. pyogenes ATCC 19615, S. aureus ATCC 25923, S. epidermidis ATCC 12228, E. coli ATCC 25922, P. aeruginosa ATCC 27853 and K. pneumoniae ATCC 13883. It was remarked that the ethanol extract of C. olympica has a strong effect $(20 \mathrm{~mm})$ against $K$. pneumoniae ATCC 13883 and the extracts of C. glomerata and C. olympica have high activity against at least one of the tested Gram (-) bacteria. However, the plant extracts had no effect against $S$. aureus, S. epidermidis and P. aeruginosa (Usta, Yildirim, \& Turker, 2014). The antibacterial effect of the aqueous extract of $V$. thapsus was tested against S. aureus PTCC1431 and E. coli HP101BA $7601 \mathrm{c}$. It was shown that the extract has an effect against Gram (+) and Gram (-) bacteria (Sepahi, Ghorani-Azam, Sepahi, Asoodeh, \& Rostami, 2014). In another study, the antimicrobial activity of volatile oil and aqueous extracts of C. portenschlagiana Roem.et Schult were evaluated. It was reported that the results of the C. portenschlagiana volatile oil have a more powerful antimicrobial activity than the aqueous extract. The volatile oil had very strong activity (19.6-28.3 mm) against Gram (+) and Gram (-) bacteria and its MIC values were 7.8-125.0 mg/mL. However, the aqueous extract of C. portenschlagiana indicated considerable effect (10.8-21.5 mm) against the tested bacteria and its MIC values were $125.0-500 \mathrm{mg} / \mathrm{mL}$. The volatile oil of the plant had the most effect $(28.3 \mathrm{~mm}-7.8 \mathrm{mg} / \mathrm{mL})$ against $P$. aeruginosa FNSST 014 while the aqueous extract of $C$. portenschla- 
giana had the most effect $(21.5 \mathrm{~mm}-125.0 \mathrm{mg} / \mathrm{mL})$ against $\mathrm{S}$. aureus ATCC 25923 (Politeo, Skocibusic, Burcu, Maravic, Carev, Ruscic, \& Milos, 2013). In another study, the aerial parts of $V$. lagurus Fisch. \& C.A.Mey., V. gnaphalodes M. Bieb., and V.xanthophoeniceum Griseb. were extracted with methanol, chloroform, ethyl acetate and water. The ethyl acetate extract of $V$. lagurus demostrated higher antimicrobial activity among the other $V$. lagurus extracts. The methanol, chloroform, ethyl acetate and water extracts of $V$. lagurus had an effect against $S$. aureus and the MIC values were $156-625 \mathrm{mg} / \mathrm{L}$. The methanol extract of $V$. lagurus showed only against $P$. aeruginosa. In addition, the methanol, ethyl acetate and aqueous extracts of $V$. lagurus had a moderate effect against C. albicans (Şen, Döşler, \& Meriçli, 2012). In a similar study, the antibacterial activity of the aqueous and ethanol extracts of $V$. speciosum flowers were evaluated against B. subtilis, E. aerogenes, P. vulgaris and S. paratyphi. It was shown that the ethanol extract had a slight effect (10-11 mm) against $E$. aerogenes and S. paratyphi and the aqueous extract did not inhibit the selected bacteria (Noori, Malayeri, Moosaei, Pakzad, \& Piriye, 2012).

When the results of our study are compared with the previous study results, the antimicrobial activities of C. tomentosa extracts (especially ethyl acetate and methanol extracts) indicated a higher effect than C. portenschlagiana, C. glomerata, $C$. olympica, C. latifolia, C. retrorsa, and C. lyrata subsp. lyrata extracts. Also, antimicrobial activities of $V$. mykales extracts were found to be more effective than the antimicrobial activity of other Verbascum species.

\section{CONCLUSION}

In this study, we investigated the antimicrobial activity of C. tomentosa and $V$. mykales endemic plant extracts against some microorganisms. It was determined that ethyl acetate and methanol extracts of plants showed high activity against the tested microorganisms. The results obtained will contribute to the pharmaceutical industry as a novel drug discovery.

Peer-review: Externally peer-reviewed.

Author Contributions: Conception/Design of study- E.P.Ç.; Data ACquisition- E.B.; Data Analysis/Interpretation- E.P.Ç., E.B.; Drafting Manuscript- E.P.Ç.; Critical Revision of Manuscript- E.P.Ç.; Final Approval and Accountability- E.P.Ç.; Technical or Material Support- E.P.Ç., E.B.

Conflict of Interest: The authors have no conflict of interest to declare.

Financial Disclosure: This study was funded by Scientific Research Projects Coordination Unit of Aydin Adnan Menderes University (Project number: FEF-17039).

Acknowledgement: This work was carried out by Aydin Adnan Menderes University Biology Department, Microbiology Laboratory. We thank Assoc. Prof. Dr. Özkan EREN for tlie support provided to us in the collection and identification of plants.

\section{REFERENCES}

Abdallah, L., \& Omar, G. (2019). Antibacterial effect of some wild medicinal plants in Paletsine against multi drug resistant Escherichia coli clinical isolate. Brazilian Journal of Biological Sciences, 6(12), 103-113.
Alhage, J., Elbitar, H., Taha, S., \& Benvegnu, T. (2018). Invitro assessment of antioxidant, antimicrobial, cytotoxic, antiinflammatory and antidiabetic activities of Campanula retrorsa crude extracts. Pharmacognosy Research, 10, 39-403.

Amirnia, R., Khoshnoud, H., Alahyary, P., Ghiyasi, M., Tajbakhsh, M., \& Valizadegan, O. (2011). Fresenius Environmental Bulletin, 20(3a), 690-693.

- Baytop, T. (1999). Türkiye'de bitkiler ile tedavi, geçmişte ve bugün. Nobel Tip Kitabevleri, II. Baskı, (pp. 480), İstanbul, Türkiye.

- $\quad$ Balouiri, M., Sadiki, M., \& Ibnsouda, S. K. (2016). Methods for in vitro evaluating antimicrobial activity: A review. Journal of Pharmaceutical Analysis, 6(2), 71-79.

- $\quad$ Benli, M., Bingol, U., Geven, F., Guney, K., \& Yigit, N. (2008). An investigation on the antimicrobial activity of some endemic plant species from Turkey. African Journal of Biotechnology, 7(1), 1-5.

Bıyık, H. H., Onur, M., Törün, B., \& Çoban, E. P. (2018). Antibacterial and anticandidal effects of the leaf extracts of Persea americana Mill. Annals of Phytomedicine, 7(2), 88-93.

- Borchardt, J. R., Wyse, D. L., Sheaffer, C. C., Kauppi, K. L., Fulcher, R. G., Ehlke, N. J., Biesboer, D. D., \& Bey, R. F. (2008). Antimicrobial activity of native and naturalized plants of Minnesota and Wisconsin. Journal of Medicinal Plant Research, 2(5), 98-110.

- Buruk, K., Sokmen, A., Aydin, F., \& Erturk, M. (2006). Antimicrobial activity of some endemic plants growing in the Eastern Black Sea Region, Turkey. Fitoterapia, 77: 388-391.

- Clinical and Laboratory Standards Institute. (2004). Method for antifungal disk diffusion susceptibility testing of yeasts, approved guideline. CLSI document M44-A. Wayne, PA, USA.

- Clinical and Laboratory Standards Institute. (2009). M07-A8: Methods for dilution antimicrobial susceptibility testing for bacteria that grow aerobically: Approved Standard (8 $\left.8^{\text {th }} e d\right)$. (pp. 1-65). CLSI, Wayne, PA, USA.

- Clinical and Laboratory Standards Institute. (2013). Performance standards for antimicrobial disk and dilution susceptibility tests for bacteria isolated from animals; approved standard. CLSI document VET01-A4(4 ${ }^{\text {th }}$ ed). CLSI, Wayne, PA, USA.

- Clinical and Laboratory Standards Institute. (2015). M02-A12: Performance standards for antimicrobial disk susceptibility tests: Approved standard. (12 $2^{\text {the }}$ ). (pp. 1-73). CLSI, Wayne, PA, USA.

Collins, C. H., Lyne, P. M., Grange, J. M., \& Falkinham, J. O. (2004). Collins and Lyne's microbiological methods ( $8^{\text {th }}$ ed). (pp. 456). London: Butterworths.

- Coşkun, M. I., Gemici, M., \&Yildirim, H. (2017). A study on endogenous hormone levels and phenolic profiles in embryogenic and non- embryogenic calli of endemic plant Campanula tomentosa L. Asian Journal of Biology, 4(2), 1-7.

- Çoban, E. P., Bıyık, H. H., Törün, B., \& Yaman, F. (2017). Evaluation the antimicrobial effects of Pistacia terebinthus L. and Papaver rhoeas $\mathrm{L}$. extracts against some pathogen microorganisms. Indian Journal of Pharmaceutical Education and Research, 51(3), 377-380.

- Çoban, E. P., Erçin, Z., Törün, B., \& Bıyık, H. H. (2018). Antimicrobial effects of the stem extracts of Apium graveolens Mill. Annals of Phytomedicine, 7(2), 70-75.

- Dar, R. A., Shahnawaz, M., \& Qazi, P. H. (2016). General overview of medicinal plants: A review. Journal of Phytopharmacy, 6(6), 349-351. Dulger, B., Kirmizi, S., Arslan, H., Güleryüz, G. (2002). Antimicrobial activity of three endemic Verbascum species. Pharmaceutical Biology, 40(8): 587-589.

- Dulger, B., \& Dulger, G. (2018). Antibacterial activity of Verbascum antinori. Konuralp Tip Dergisi, 10(3), 395-398.

- Dülger, B., \& Hacıoğlu, N. (2008). Antimicrobial activity of some endemic Verbascum and Scrophularia species from Turkey. Asian Journal of Chemistry, 20(5), 3779-3785.

EUCAST (2019). Disk diffusion method for antimicrobial susceptibility testing (Version 7.0). 
- $\quad$ Fares, S. S. F. (2018). Antimicrobial activities and phytochemical analysis of Verbascum fruticulosum (Master DegreeThesis). AnNajah National University Faculty of Graduate Studies.

- $\quad$ Faydaoğlu, E., \& Sürücüoğlu, M. S. (2011). Geçmişten günümüze tıbbi ve aromatik bitkilerin kullanılması ve ekonomik önemi. Kastamonu Üniversitesi Orman Fakültesi Dergisi, 11(1), 52-67.

• $\quad$ Faydaoğlu, E., \& Sürücüoğlu, M. S. (2013). Tıbbi ve aromatik bitkilerin antimikrobiyal, antioksidan aktiviteleri ve kullanım olanakları. Erzincan Üniversitesi Fen Bilimleri Enstitüsü Dergisi, 6(2), 233-265.

- Göse, M. \& Hacıoğlu Doğru (2021). Bioactive compounds, antimicrobial and antibiofilm activity of two Verbascum species. KSU Journal of Agriculture and Nature, 24(3): 479-487.

- Guarino, C. (2002). Antimicrobial activity of Verbascum macrurum Ten. (Scrophulariaceae). Bollettino Chimico Farmaceutico, 141(3), 238-242.

- Herkul, M.M, \& Köroğlu, A. (2019). A review on the ethnobotanical use, chemical content and biological activity of the Campanulaceae family. Türk Farmakope Dergisi, 4(3), 70-84.

- Ismaiel, A. A., \& Tharwat, N. A. (2014). Antifungal activity of silverion on ultra structure and production of aflatoxin $\mathrm{B} 1$ and patulin by two mycotoxigenic strains, Aspergillus flavus OC1 and Penicillium vulpinum CM1. Journal de Mycologie Médicale, 24,193-204. Jorgensen, J. H., \& Ferraro, M. J. (2009). Antimicrobial susceptibility testing: a review of general principles and contemporary practices. Journal of Medical Microbiology, 49, 1749-1755.

- $\quad$ Kahraman, Ç., Ekizoğlu, M., Kart, D., Akdemir, Z. Ş., \&Tatlı, I. I. (2011). Antimicrobial activity of some Verbascum species growing in Turkey. FABAD Journal of Pharmaceutical Sciences, 36, 11-15.

- Kahraman, Ç., Tatlı, I. I., Kart, D., Ekizoğlu, M., \& Akdemir, Z. Ş. (2018). Structure elucidation and antimicrobial activities of secondary metabolites from the flowery parts of Verbascum mucronatum Lam. Turkish Journal of Pharmaceutical Sciences, 15(3), 231-237.

- Karalija, E., Parić, A., Dahija, S., Bešta-Gajević, R., \& Zeljković, S. Ć. (2018). Phenolic compounds and bioactive properties of Verbascum glabratum subsp. Bosnense (K. Malý) Murb., an endemic plant species. Natural Product Research, 32, 1-5.

- Keskin, C. (2018). Medicinal plants and their traditional uses. Journal of Advances in Plant Biology, 1(2), 1-12.

- Khafagi, I. K. (2001). Screening in vitro cultures of some Sinai medicinal plants for their antibiotic activity. Journal Microbiology, 34: 613-627.

- Küçük, S., Özdemir, F., Işcan, G., \& Incesu, Z. (2016). Determination of cytotoxic and anticandidal activities of three Verbascum L. species fromTurkey: V. cheiranthifolium Boiss. var. asperulum (Boiss.) Murb. Monorg. V. pycnostachyum Boiss. \& Heldr and V. orgyale Boiss. \& Heldr. Turkish Journal of Pharmaceutical Sciences, 13(3), 318-322.

- Moosavi, S. R., Ardekani, M. R. S., Vazirian, M., \& Lamardi, S. N. S. (2018). Campanula latifola, giant bellflower; ethno-botany, phytochemical and antioxidant evaluation. Traditional and Integrative Medicine, 3(3), 113-119.

- Muhammad, A., Shandana, A., Khushboo, S., \& Rahila, A. (2019). Review on antibacterial activity of Himalayan medicinal plants traditionally used to treat pneumonia and tuberculosis. Journal of Pharmacy and Pharmacology, 71, 1599-1625.

- Nofouzi, K., Mahmudi, R., Tahapour, K., Amini, E., \& Yousefi, K. (2016). Verbascum speciosum methanolic extract: Phytochemical components and antibacterial properties. Journal of Essential Oil Bearing Plants, 19(2), 499-505.

- Nofouzi, K. (2015). Study on the antioxidant activity and in vitro antifungal activity of Verbascum speciosum methanolic extract. Journal of Mycology Research, 2(2), 97-103.

- $\quad$ Noori, M., Malayeri, B., Moosaei, M., Pakzad, R., \& Piriye, M.H. (2012). Effects of heavy metals on the antibacterial properties of Verbascum speciosum Schard. Revista Científica UDO Agrícola, 12(2), 463-471.

- $\quad$ Okoye, E. L., Uba, B. O., Dike, U. C., \& Eziefule, C. J. (2020). Growth rate and antifungal activities of acetone extracts of Ocimum gratissimum (ScentLeaf) and Alliumsativum (Garlic) on cassava and banana peels formulated media. Journal of Advances in Microbiology, 20(4), 19-29.
Oyeka, E. E., Asegbeloyin, J. N., Babahan, I., Eboma, B., Okpareke, O., Lane, J., Ibezim, A, Bıyık, H.H, Törün, B, \& Izuogu, D. C. (2018). Synthesis, crystal structure, computation analysis and biological properties of 1-(4-chlorobenzoyl)-3-[2-(2-\{2-[3-(4-chlorobenzoyl)thioureido]-ethoxy\} ethoxy) ethyl]-thiourea and its $\mathrm{Ni}(I)$ and $\mathrm{Cu}(\mathrm{II})$ complexes. Journal of Molecular Structure, 1168, 153-164.

- $\quad$ Ozhatay, N., Kultur, Ş., \& Aslan, ş. (2009). Check-list of additional taxa to the supplement Flora of Turkey IV. Turkish Journal of Botany, 33, 191-226.

Politeo, O., Skocibusic, M., Burcu, F., Maravic, A., Carev, I., Ruscic, M., \& Milos, M. (2013). Campanula portenschlagiana Roem.et Schult:: Chemical and antimicrobial activities. Chemistry and Biodiversity, 10: 1072-1080.

Prakash, V., Rana, S., \& Sagar, A. (2016). Studies on antibacterial activity of Verbascum thapsus. Journal of Medicinal Plants Studies, 4(3), 101-103.

- $\quad$ Sepahi, S., Ghorani-Azam, A., Sepahi, S., Asoodeh, A., \& Rostami, S. (2014). In vitro study to evaluate antibacterial and non-haemolytic activities of four Iranian medicinal plants. West Indian Medical Journal, 63(4), 289-293.

- $\quad$ Sinek, K., İskender, N, Y., Yaylı, B., Karaoğlu, S. A., \& Yaylı N. (2012). Antimicrobial activity and chemical composition of the essential oil from Campanula glomerata L. subsp. Hispida (Witasek) Hayek. Asian Journal of Chemistry, 24(5), 1931-1934.

Stojkovi'c, D., Dias, M. I., Drakuli'c, D., Barros, L., Stevanovi'c, M., Ferreira, I. C. F. R., \&Sokovi'c, M., D. (2020). Methanolic extract of the herb Ononis spinosa L. is an antifungal agent with no cytotoxicity to primary human cells. Pharmaceuticals, 13(78), 1-13.

- S S Sen, B., Döşler, S., Meriçli, A. H. (2012). The antimicrobial activity screening of three Verbascum species in Marmara region. Planta Medica, 78, Pl310.

- Tatli, I.I.., Schuhly, W., Kunert, O., Bedir, E., \& Akdemir Z. S. (2008). Secondary metabolites from the aerial parts of Verbascum dudleyanum and their biological activities. Chemistry of Natural Compounds, 44(3), 292-295.

Tatli, I., \& Akdemir. Z. S. (2005). Antimicrobial and antimalarial activities of secondary metabolites from some Turkish Verbascum species. FABAD Journal of Pharmaceutical Sciences, 30(2), 84-92.

- Temel, M. Tınmaz, B. Öztürk, M. \& Gündüz, O. (2018). Dünyada ve Türkiye'de tıbbi-aromatik bitkilerin üretimi ve ticareti. KSU Journal of Agriculture and Nature, 21 (Special Issue): 198-214.

Tosun, G. Kahrıman, N. Çoskun Çelebi, K. Genç, H. Alpay Karaoglu, S. \& Yaylı, N. (2011). Chemical composition and biological activity of the essential oil of Campanula olympica Boiss. Asian Journal of Chemistry, 23(6), 2389-2391.

Törün, B., Çoban, E. P., Bıyık, H. H., \& Barışı, E. (2017). Antimicrobial activity of Echinophora tenuifolia L. and Raphanus sativus L. extracts. Indian Journal of Pharmaceutical Education and Research, 51(3), 373-376.

Turker, H., \& Yıldırım, A. B. (2015). Screening for antibacterial activity of some Turkish plants against fish pathogens: a possible alternative in thetreatment of bacterial infections. Biotechnology and Biotechnological Equipment, 29(2), 281-288.

Usta, C., Yildirim, B. A., \& Turker, U. A. (2014). Antibacterial and antitumor activities of some plants grown in Turkey. Biotechnology and Biotechnological Equipment, 28(2), 306-315.

Yaldız, G., \& Çamlıca, M. (2018). Türkiye'de tıbbi ve aromatik bitkilerin üretimi ve ticareti. Bahçe, 47: (Özel Sayı): 224-229.

- Zamri, N. A. F. M., Bakar, R. A., Noor, S. S. M., \& Fuad, W. E. M. (2020). Antimicrobial effects of Peperomia pellucida (Ketumpang Air) against multi drug resistant and foodborne organisms including toxicity study in Sprague Dawley rats. Asian Journal of Medicine and Biomedicine, elSNN: 2600-8173. 